\title{
Efektivitas Penggunaan Modul Termokimia Berbasis Inkuiri Terbimbing Terintegrasi Eksperimen Terhadap Hasil Belajar Peserta Didik
}

\author{
Penulis: \\ Finny Rahmatania ${ }^{1}$ \\ Andromeda ${ }^{2}$ \\ Fanny Rahmatina Rahim ${ }^{3}$ \\ Afiliasi: \\ Universitas Negeri \\ Padang $1,2,3$ \\ Korespondensi: \\ finnyrahmatania@gmail.com \\ Histori Naskah: \\ Submit: 99-00-9999 \\ Accepted: 99-00-9999 \\ Published: 99-00-9999 \\ This is an Creative Commons License \\ This work is licensed under a Creative \\ Commons Attribution-NonCommercial \\ 4.0 International License
}

\begin{abstract}
:
Background: Chemistry learning in thermochemistry material has not been able to guide students to finding concept by themselves. Because of this, teaching materials are needed modules that apply the model guided inquiry integrated experiment.

Method: This research aims to determined the effectiveness of uses thermochemistry module based on guided inquiry integrated experiments with student learning outcomes. The type of this research was Randomized Pretest-posstest Control Group Design. The population were students of class XI MIPA SMAN 3 Padang as much as 8 classes. The samples was chosen using a purposive-cluster random sampling technique, obtained XI MIPA 7 as experiment class and XI MIPA 4 as control class.Data analysis in this research was students learning outcome in cognitive domain.

Result: The avarage value of control class was 80,42 and experiment class was 84,58. From the results statistic, both two sample classes had normal and homogenous. Based on the hypotesis using t-test wit significance level of 0,05 was found tcount was 3,32 and ttable was 1,66., it means $H \mathrm{l}$ was accepted. In addition, to know the effectiveness of thermochemistry module based on guided inquiry integrated experiment it can be seen using the $\mathrm{N}$-Gain skor.

Conclusion: So it can be conclude that module is effective to improving student learning outcomes in the XI MIPA at SMAN 3 Padang.
\end{abstract}

keywords: effectiveness, module, guided inquiry, thermochemistry

\section{Pendahuluan}

Termokimia merupakan salah satu materi pembelajaran Kimia Sekolah Menengah Atas (SMA) Kelas XI Semester 1. Materi ini merupakan materi awal dalam mengenal keterkaitan hubungan reaksi kimia dengan perubahan energi (panas) yang menyertainya. Pada materi termokimia terdapat keterkaitan konsep dengan kehidupan sehari-hari. Oleh karena itu, dibutuhkan suatu metode pembelajaran yang dapat mengaitkan konsep dengan kehidupan sehari-hari yaitu eksperimen. Pembelajaran menggunakan metode eksperimen merupakan teknik mengajar yang dilakukan guru dengan cara meminta peserta didik melakukan percobaan tentang suatu hal, mengamati prosesnya dan menuliskan hasil percobaan yang dilakukan (Roestiyah,2008: $80)$.

Berdasarkan wawancara yang dilakukan dengan beberapa orang guru kimia di SMAN 3 Padang bahwa penerapan metode eksperimen pada materi termokimia dilakukan secara kondisional. Hal ini tergantung pada keadaan laboratorium serta waktu yang cocok untuk dilaksanakan praktikum. Pada umumnya, praktikum dilaksanakan setelah peserta didik menemukan konsep atau mempelajari teori di dalam kelas. 
Selain itu, peserta didik masih belum bisa menemukan konsep tanpa bantuan guru. Hal ini dikarenakan peserta didik cenderung menghafalkan rumus-rumus sehingga kesulitan mengaitkan konsep yang telah didapatkan dan mengakibatkan peserta didik kesulitan mengerjakan soal-soal (Ninik, 2016: 48). Oleh karena itu, guru harus mampu untuk membimbing peserta didik dalam memahami konsep dan mengaplikasikan langsung konsep yang didapatkan.

\section{Studi Literatur}

Dalam proses pembelajaran dibutuhkan media sebagai sumber belajar agar pembelajaran berjalan efektif. Salah satu sumber belajar yang dapat digunakan dalam pembelajaran kimia adalah bahan ajar berupa modul. Modul adalah seperangkat bahan ajar yang disajikan secara sistematis sehingga dapat digunakan dalam kegiatan belajar mengajar (Depdiknas, 2008: 20).

Penggunaan modul dalam pembelajaran berguna untuk membantu guru dalam menyampaikan materi dan membantu peserta didik memahami materi melalui bimbingan guru. Selain itu, penggunaan modul mampu membuat peserta didik belajar secara aktif dan mandiri secara maksimal (Iqma dkk, 2013). Hal ini sesuai dengan teori belajar yang dikemukakan oleh Piaget (dalam Amri, 2013) yang mengungkapkan bahwa pengetahuan yang didapatkan akan bermakna apabila dicari dan diselidiki secara mandiri oleh peserta didik. Oleh karena itu, disusun sebuah modul yang berbasis pada salah satu model pembelajaran yaitu inkuiri terbimbing. Bahan ajar berupa modul berbasis inkuiri terbimbing disusun sesuai dengan siklus belajar inkuiri terbimbing. Inkuiri terbimbing merupakan model pembelajaran yang digunakan guru untuk menemukan konsep. Bimbingan yang diberikan akan dikurangi seiring dengan perkembangan belajar peserta didik. Penggunaan model inkuiri terbimbing dalam proses pembelajaran dapat mengurangi sifat pasif peserta didik dan pembelajaran tidak terkesan teacher center. Oleh karena itu, guru hanya berperan sebagai fasilitator yang menstimulasi dan memotivasi, menumbuhkan pemahaman, dan memberikan kesempatan kepada peserta didik untuk aktif dalam mengikuti pembelajaran (Nurdyansyah \& Eni, 2016 : 150)

Kegiatan pembelajaran yang dilakukan peserta didik mengikuti cara kerja ilmuwan, seperti melakukan identifikasi masalah, membuat dugaan sementara (hipotesis), melakukan kegiatan pengumpulan data, menguji hipotesis, dan membuat kesimpulan (Maikristina, 2013). Menurut Hanson (2005 : 1), dalam membimbing peserta didik menemukan konsep, aktivitas pembelajaran inkuiri terbimbing terdiri dari lima tahap, yaitu : orientasi, eksplorasi, pembentukan konsep, aplikasi, dan penutup. Pada tahap orientasi, guru memberikan penjelasan singkat mengenai materi yang akan dipelajari guna memberikan motivasi dan menarik peserta didik untuk belajar. Pada tahap ini guru harus membantu peserta didik dalam menghubungkan materi yang akan dipelajari dengan pengetahuan awal (prior knowlegde) yang dimiliki sebelumnya. Pengetahuan awal merupakan pengetahuan yang dimiliki peserta didik sebelum menerima materi yang dipelajari (Astuti, 2015: 73)

Pada tahap eksplorasi dan pembentukan konsep, peserta didik mengidentifikasi suatu informasi/model yang diberikan, baik berupa tabel, diagram, grafik, data hasil eksperimen, dan lain-lain. Selanjutnya, peserta didik melakukan analisis data, mengumpulkan informasi, menanyakan, dan menguji hipotesis dari data yang didapatkan. Konsep-konsep yang telah diidentifikasi, dieksplorasi dengan dibimbing melalui pertanyaan kunci. Pertanyaan kunci merupakan pertanyaan yang membimbing peserta didik dalam menganalisis data dan menemukan konsep sendiri. Pertanyaan-pertanyaan disusun saling berhubungan mulai dari tingkat kesulitan rendah ke tingkat kesulitan tinggi agar peserta didik mampu berfikir secara terstruktur dan kritis terhadap informasi yang telah ditemukan.

Pada tahap aplikasi, konsep yang sudah didapatkan peserta didik diaplikasikan dalam bentuk pemberian latihan berupa soal-soal. Soal-soal diberikan sesuai dengan konsep yang telah didapatkan saja dengan tingkat kesulitan yang bervariasi. Hal ini bertujuan untuk memberikan kesempatan kepada peserta didik 
dalam membangun kepercayaan diri ketika dihadapkan pada suatu permasalahan. Pada tahap akhir yaitu penutup, peserta didik diminta untuk menyimpulkan konsep-konsep baru yang sudah didapatkan, baik secara individu maupun berkelompok.

Modul yang digunakan dalam penelitian ini adalah modul termokimia berbasis inkuiri terbimbing terintegrasi ekperimen. Modul ini disusun oleh Alfirahmi yang telah diuji validitas dan praktikalitas. Modul ini berisi uraian materi termokimia yang akan diajarkan kepada peserta didik kelas XI MIPA SMA/MA. Berdasarkan penelitian yang telah dilakukan, modul tersebut memiliki tingkat kevalidan yang tinggi dengan nilai momen kappa sebesar 0,82 dan sangat praktis ketika diujicobakan kepada guru dan peserta didik dengan momen kappa 0,93 dan 0,81 (Alfirahmi, 2018: 16). Dapat disimpulkan bahwa modul dapat digunakan untuk diuji efektivitas penggunaannya dalam pembelajaran.

Penelitian ini dilakukan untuk mengetahui efektivitas penggunaan modul termokimia berbasis inkuiri terbiming terintegrasi eksperimen terhadap hasil belajar peserta didik kelas XI MIPA di SMA Negeri 3 Padang.

\section{Metode Penelitian}

Jenis penelitian ini adalah Quasi Experiment atau eksperimen semu. Desain penelitian yang digunakan adalah Randomized Pretest-Posttest Control Group Design. Pada desain penelitian ini, diperoleh 2 kelas sampel yang dipilih menggunakan kombinasi dari beberapa teknik pengambilan sampel, seperti purposive, random, dan cluster sampling. Dari kombinasi tersebut, didapat sebuah teknik pengambilan sampel, yaitu purposive-cluster random sampling. Dari kedua kelas sampel akan ditentukan 1 buah kelas eksperimen dan 1 buah kelas kontrol. Dalam pembelajaran, kelas eksperimen menggunakan modul termokimia berbasis inkuiri terbiming terintegrasi eksperimen, sedangkan kelas kontrol menggunakan buku yang disediakan di sekolah. Desain penelitian ini dapat dilihat pada Tabel 1.

Tabel 1 Desain Penelitian

\begin{tabular}{|c|c|c|c|}
\hline Kelompok & Pretest & Perlakuan & Posttest \\
\hline Kelas Kontrol & $\mathrm{O}_{1}$ & $\mathrm{X}_{1}$ & $\mathrm{O}_{2}$ \\
\hline $\begin{array}{c}\text { Kelas } \\
\text { Eksperimen }\end{array}$ & $\mathrm{O}_{1}$ & $\mathrm{X}_{2}$ & $\mathrm{O}_{2}$ \\
\hline
\end{tabular}

Sumber : (Sugiyono, $2015: 118$ )

Keterangan : $\mathrm{O}_{1}=$ Pretest, $\mathrm{O}_{2}=$ Posttest, $\mathrm{X}_{1}=$ Pembelajaran yang menggunakan bahan ajar yang disediakan sekolah, $\mathrm{X}_{2}=$ Pembelajaran yang menggunakan modul berbasis inkuiri terbimbing terintegrasi eksperimen

Populasi adalah sekumpulan objek dengan karakteristik tertentu sebagai bahan penelitian yang ditetapkan peneliti (Sugiyono, 2013: 297). Populasi dalam penelitian ini adalah seluruh peserta didik kelas XI IPA di SMA Negeri 3 Padang semester ganjil Tahun Ajaran 2019/2020.

Sampel adalah bagian dari jumlah dan karakteristik yang dimiliki oleh populasi tersebut (Sugiyono, 2013: 117). Dengan menggunakan kombinasi dari beberapa teknik pengambilan sampel, didapatkan 2 kelas sampel yaitu XI MIPA 4 sebagai kelas kontrol dan XI MIPA 7 sebagai kelas eksperimen.

Variabel dalam penelitian ini adalah variabel bebas, terikat, dan kontrol. Variabel bebas pada penelitian ini adalah pembelajaran yang menggunakan modul berbasis inkuiri terbimbing terintegrasi eksperimen. Variabel terikat pada penelitian ini adalah hasil belajar peserta didik yang diperoleh dari pretest dan posttest. Variabel kontrol pada penelitian ini adalah guru, mata pelajaran, alokasi waktu, dan kurikulum. 
Jenis data terdiri atas dua yaitu data primer dan data sekunder. Data primer pada penelitian ini adalah hasil pretest dan posttest, sedangkan data sekunder yaitu hasil ulangan harian peserta didik.

Penelitian ini terdiri dari tiga tahap, yaitu persiapan, pelaksanaan, dan penyelesaian. Tahap pertama, mempersiapakan Rancangan Pelaksanaan Pembelajaran (RPP) untuk kelas kontrol dan eksperimen, soal uji coba, analisis soal uji coba, dan pretest sebelum melaksanakan pembelajaran. Soal uji coba dipersiapkan sebanyak 30 soal objektif dan dianalisis sehingga menghasilkan 20 soal yang akan digunakan sebagain instrumen penilaian Tahap kedua melaksanakan pembelajaran dan tahap ketiga memberikan tes akhir kepada kedua kelas sampel.

Instrumen penilaian yang digunakan adalah tes tertulis untuk penilaian hasil belajar pada ranah kognitif sebanyak 20 soal objektif. Teknik analisa data yang digunakan yaitu uji perbedaan dua rata-rata atau uji-t. Untuk dapat melakukan uji-t, terlebih dahulu dilakukan uji normalitas dan uji homogenitas. Untuk menguji normalitas suatu sampel digunakan Uji Liliefors (Agus, 2015, 275). Untuk menguji normalitas suatu sampel, digunakan Uji Liliefors (Agus, 2015, 275). Untuk mengetahui homogenitas sampel, digunakan uji Hartley $(\mathrm{F})$, dengan menggunakan rumus,

$$
\mathrm{F}=\frac{S_{1}^{2}}{S_{2}^{2}}
$$

Keterangan : $\mathrm{F}=$ Varians kelompok data, $\mathrm{S}_{1}{ }^{2}=$ Varians hasil belajar terbesar, dan $\mathrm{S}_{2}{ }^{2}=$ Varians hasil belajar terkecil

Berdasarkan hasil pengolahan data, didapatkan bahwa kedua kelas sampel terdistribus normal dan memiliki varians yang homogen. Dengan begitu, uji hipotesis dapat dilakukan dengan menggunakan uji-t, menggunakan persamaan

$$
t=\frac{\overline{X_{1}}-\overline{X_{2}}}{S \sqrt{\frac{1}{n_{1}}+\frac{1}{n_{2}}}}
$$

dimana:

$$
S^{2}=\frac{\left(n_{1}-1\right) S_{1}^{2}+\left(n_{2}-1\right) S_{2}^{2}}{n_{1}+n_{2}-2}
$$

dengan $\overline{X_{1}}$ adalah nilai rata-rata kelas eksperimen, $\overline{X_{2}}$ adalah nilai rata-rata kelas kontrol, $S^{2}$ adalah variansi, $S_{1}$ adalah standar deviasi kelas eksperimen, $S_{2}$ adalah standar deviasi kelas kontrol, $S$ adalah standar deviasi gabungan, $n_{1}$ adalah jumlah peserta didik kelas eksperimen, dan $n_{2}$ adalah jumlah peserta didik kelas kontrol.

Uji N-Gain dilakukan untuk mengetahui keefektifan modul termokimia berbasis inkuiri terbimbing terintegrasi eksperimen yang dapat dilihat melalui selisih pretest dan posttest. Uji N-Gain dapat dicari menggunakan rumus:

$$
\text { Rata-rata N-Gain }=\frac{\Sigma N-\text { Gain siswa }}{\text { jumlah siswa }}
$$

\section{Hasil}

Data yang diperoleh dari hasil penelitian adalah pretest dan posttest yang diberikan kepada 36 orang peserta didik kelas komtrol dan kelas eksperimen. Rata-rata nilai pretest kelas kontrol dan kelas eksperimen sebesar 33,61 dan 25,83. Sedangkan rata-rata nilai kelas eksperimen sebesar 84,58 dan kelas kontrol sebesar 80,42. 


\section{Analisis Data}

Analisis data yang dilakukan adalah uji normalitas dan homogenitas pada kelas sampel, uji hiptesis menggunakan uji-t, dan uji N-Gain. Dari selisih nilai pretest dan posttest peserta didik, didapatkan rata-rata $(\bar{X})$, simpangan baku $(\mathrm{S})$, dan varians $\left(\mathrm{S}^{2}\right)$. Secara ringkas dapat dilihat pada Tabel 2

Tabel 2 Nilai Rata-rata, Simpangan Baku, dan Varians Kelas Eksperimen dan Kelas Kontrol

\begin{tabular}{|l|c|c|c|c|}
\hline Kelas & $\mathrm{N}$ & $\bar{X}$ & $\mathrm{~S}$ & $\mathrm{~S}^{2}$ \\
\hline Kontrol & 36 & 46,81 & 15,91 & 253,15 \\
\hline Eksperimen & 36 & 58,75 & 14,41 & 207,65 \\
\hline
\end{tabular}

Dari tabel diatas, dapat dilihat bahwa rata-rata selisih nilai pretest dan posttest kelas eksperimen lebih tinggi dibandingkan kelas kontrol. Untuk mengetahui efektivitas penggunaan modul termokimia berbasis inkuiri terbimbing terintegrasi eksperimen dapat dilakukan dengan menggunakan uji N-Gain yang dapat dilihat pada Tabel 3

Tabel 3 Hasil Uji N-Gain Kelas Sampel

\begin{tabular}{|l|c|c|c|}
\hline Kelas & $\mathrm{N}$ & $\begin{array}{c}\text { Rata-rata N- } \\
\text { Gain }\end{array}$ & Keterangan \\
\hline Kontrol & 36 & 0,69 & Sedang \\
\hline Eksperimen & 36 & 0,79 & Tinggi \\
\hline
\end{tabular}

Pada Tabel 3 dapat dilihat bahwa nilai N-Gain kelas eksperimen lebih tinggi daripada kelas kontrol. Hal tersebut berarti nilai N-gain kelas eksperimen berada pada kategori tinggi. Selanjutnya pengujian hipotesis pada penelitian ini. Sebelum melakukan uji hipotesis, terlebih dahulu dilakukan uji normalitas dan homogenitas pada kelas sampel. Analisis uji normalitas dapat dilihat pada Tabel 4

Tabel 4 Uji Normalitas Terhadap Kelas Sampel

\begin{tabular}{|c|c|c|c|c|}
\hline Kelas & $\alpha$ & Lo & Lt & Keterangan \\
\hline Kontrol & \multirow{2}{*}{0,05} & 0,118 & 0,1476 & Normal \\
\cline { 1 - 4 } Eksperimen & & 0,103 & 0,1476 & Normal \\
\hline
\end{tabular}

Dari Tabel 4, masing-masing kelas sampel memiliki nilai $\mathrm{L}_{\mathrm{o}}$ max lebih rendah dibandingkan nilai $\mathrm{L}_{\mathrm{t}}$. Hal ini menunjukkan bahwa kelas sampel terdistribusi normal. Berikutnya uji homogenitas pada kedua kelas sampel yang telah diringkas pada Tabel 5

Tabel 5 Uji Homogenitas Terhadap Kelas Sampel

\begin{tabular}{|c|c|c|c|c|}
\hline No & Kelas & Fh & Ft & Ket \\
\hline 1 & $\begin{array}{c}\text { XI MIPA } \\
4 \text { dan 7 }\end{array}$ & 1,22 & 1,82 & Homogen \\
\hline
\end{tabular}

Pada Tabel 5 dapat dilihat bahwa nilai $\mathrm{F}_{\mathrm{h}}$ lebih kecil dibandingkan nilai $\mathrm{F}_{\mathrm{t}}$. Hal tersebut membuktikan bahwa kedua kelas sampel memiliki varians yang homogen. Dari analisis data pada pengujian normalitas dan homogenitas, dapat disimpulkan bahwa kedua kelas sampel terdistribusi normal dan memiliki varians 
yang homogen. Oleh karena itu, dapat dilakukan uji hipotesis dengan menggunakan uji-t. Adapun hasil uji hipotesis dapat dilihat pada Tabel 6

Tabel 6 Hasil Uji-t Terhadap Kelas Sampel

\begin{tabular}{|l|c|c|c|c|c|}
\hline Kelas & $\mathrm{N}$ & $\bar{X}$ & $\mathrm{~S}^{2}$ & $\mathrm{t}_{\mathrm{h}}$ & $\mathrm{t}_{\mathrm{t}}$ \\
\hline Kontrol & 36 & 46,81 & 253,15 & & \\
\cline { 1 - 4 } $\begin{array}{l}\text { Eksperi } \\
\text { men }\end{array}$ & 36 & 58,75 & 207,65 & 3,32 & 1,665 \\
\hline
\end{tabular}

Berdasarkan analisis data yang dilakukan didapatkan $t_{h}>t_{t}$, sehingga $H_{0}$ ditolak pada taraf nyata 0,05 . Hal ini menunjukkan bahwa hasil belajar peserta didik mengggunakan modul termokimia berbasis inkuiri terbimbing terintegrasi eksperimen lebih tinggi secara signifikan dibandingkan hasil belajar peserta didik tanpa menggunakan modul termokimia berbasis inkuiri terbimbing terintegrasi eksperimen.

\section{Pembahasan}

Populasi adalah sekumpulan objek dengan karakteristik tertentu sebagai bahan penelitian yang ditetapkan peneliti (Sugiyono, 2013: 297). Populasi dalam penelitian ini adalah seluruh peserta didik kelas XI IPA di SMA Negeri 3 Padang semester ganjil Tahun Ajaran 2019/2020.

Sampel adalah bagian dari jumlah dan karakteristik yang dimiliki oleh populasi tersebut (Sugiyono, 2013: 117). Dengan menggunakan kombinasi dari beberapa teknik pengambilan sampel, didapatkan 2 kelas sampel yaitu XI MIPA 4 sebagai kelas kontrol dan XI MIPA 7 sebagai kelas eksperimen.

Variabel dalam penelitian ini adalah variabel bebas, terikat, dan kontrol. Variabel bebas pada penelitian ini adalah pembelajaran yang menggunakan modul berbasis inkuiri terbimbing terintegrasi eksperimen. Variabel terikat pada penelitian ini adalah hasil belajar peserta didik yang diperoleh dari pretest dan posttest. Variabel kontrol pada penelitian ini adalah guru, mata pelajaran, alokasi waktu, dan kurikulum.

Jenis data terdiri atas dua yaitu data primer dan data sekunder. Data primer pada penelitian ini adalah hasil pretest dan posttest, sedangkan data sekunder yaitu hasil ulangan harian peserta didik.Pada pembelajaran materi termokimia dapat menggunakan model pembelajaran inkuiri terbimbing. Model pembelajaran inkuiri terbimbing terdiri dari 5 tahap, yaitu orientasi, eksplorasi, pembentukan konsep, aplikasi, dan penutup (Hanson, 2005). Model pembelajaran inkuiri terbimbing merupakan model pembelajaran yang terpusat kepada peserta didik (student center approach). Model pembelajaran ini digunakan terhadap dua buah kelas sampel, yaitu kelas kontrol dan kelas eksperimen. Pada kelas kontrol, peserta didik menggunakan buku cetak karangan Unggul Sudarmo. Sedangkan kelas eksperimen menggunakan modul termokimia berbasis inkuiri terbimbing terintegrasi eksperimen. peserta didik yang menggunakan modul ini mampu belajar secara mandiri dan khusus pada materi yang membutuhkan eksperimen peserta didik mampu melakukan sendiri dalam menemukan konsep, sehingga peserta didik memperoleh pengalaman yang lebih bermakna dan mampu mengingat dalam jangka waktu yang lama (Andromeda dkk, 2016). Pembelajaran yang bermakna diperoleh peserta didik dari kegiatan yang mengaitkan materi pelajaran dengan kejadian yang dekat dengan kehidupan sehari-hari. Sehingga mampu meningkatkan prestasi belajar baik dalam proses maupun hasil tes ( Liena, 2015 : 19).

Pada proses pembelajaran peserta didik akan dibagi menjadi beberapa kelompok-kelompok kecil dengan menggunakan siklus belajar terbimbing dan membangun konsep dan pemahaman sendiri sehingga dapat mengingat lebih banyak konsep yang didapatkan (Straumanis, 2010 : 42). Pembelajaran menggunakan modul ini dapat diamati peserta didik berperan aktif dalam melaksanakan pembelajaran, terutama pada kegiatan praktikum. Hal ini dikarenakan peserta didik belum pernah melaksanakan praktikum sebelumnya. 
Sehingga peserta didik menjadi antusias ketika dihadapkan pada pembelajaran yang mengaitkan dalam kehidupan nyata.

Pada tahap orientasi, peserta didik membaca materi pendukung terkait materi yang akan dipelajari selama 5 menit. Pada tahap ini merangsang peserta didik agar termotivasi dalam mempelajari materi tersebut. Pada tahap eksplorasi dan pembentukan konsep, peserta didik mulai menemukan konsep melalui model berupa model yang disajikan modul, berupa gambar, grafik, tabel, dan lain-lain. Pada tahap ini, peserta didik berdiskusi dengan teman kelompok dalam membangun konsep melalui pertanyaan kunci yang disajikan modul. Pertanyaan kunci merupakan pertanyaan pertanyaan yang menuntun peserta didik berfikir secara kritis dan terstruktur sehingga peserta didik dapat menemukan konsep secara mandiri. Guru membimbing peserta didik dalam memahami pertanyaan kunci yang disajikan. Pertanyaan kunci disajikan agar konsep yang didapatkan peserta didik terstruktur dari pertanyaan mendasar hingga pertanyaan lebih dalam terkait materi.

Pada materi yang membutuhkan praktikum, peserta didik terlebih dahulu mengerjakan soal pre-lab untuk mengetahui kemampuan awal terkait materi yang akan dilaksanakan pada praktikum. Kemudian peserta didik melaksanakan praktikum dan menjawab pertanyaan kritis agar konsep yang didapatkan lebih sempurna. Pada tahap pembentukan konsep, seperti pada materi reaksi eksoterm dan endoterm guru menekankan kepada peserta didik bahwa suhu yang dirasakan ketika logam Mg yang dimasukkan ke dalam tabung reaksi yang berisi $\mathrm{HCl}$ adalah suhu lingkungan. Kemudian pada tahap aplikasi, peserta didik menyelesaikan pertanyaan serupa terkait konsep yang telah didapatkan. Pada tahap penutup, guru meminta perwakilan peserta didik menyimpulkan konsep yang telah didapatkan. Kemudian, pada akhir pembelajaran, guru meminta peserta didik menyelesaikan lembar kegiatan yang terdapat pada akhir materi. Dari awal hingga diakhir pembelajaran peserta didik berperan aktif dalam menemukan konsep dengan dibantu oleh modul yang memiliki pertanyaan kritis, peserta didik mampu menyelesaikan permasalahan secara mandiri (Sevira dkk, 2018).

Pada pembelajaran kimia di kelas kontrol, peserta didik menggunakan bahan ajar berupa buku cetak karangan Unggul Sudarmo. Buku cetak ini tidak memuat pertanyaan kunci, hanya berupa uraian materi yang pada akhir materi disajikan beberapa pertanyaan yang berkaitan dengan materi yang dijelaskan. Pertanyaan-pertanyaan tersebut tidak saling berhubungan dan membimbing peserta didik dalam menemukan konsep. sehingga peserta didik kesulitan dalam membangun pemahaman konsep.

Penggunaan modul termokimia berbasis inkuiri terbimbing terintegrasi eksperimen memiliki beberapa kelebihan diantaranya; 1) peserta didik kelas eksperimen lebih aktif dalam mengikuti pembelajaran dibandingkan kelas kontrol, karena bahan ajar yang digunakan membuat peserta didik mampu menyelesaikan masalah melalui pertanyaan kunci yang disajikan, 2) peserta didik kelas eksperimen dapat berfikir secara kritis dan terstruktur karena pertanyaan kunci disediakan mulai dari pertanyaan umum hingga khusus, 3) Hasil belajar pada ranah kognitif kelas eksperimen lebih tinggi dibandingkan kelas kontrol.

\section{Kesimpulan}

Berdasarkan penelitian yang telah dilaksanakan dapat disimpulkan bahwa modul termokimia berbasis inkuiri terbimbing terintegrasi eksperimen efektif meningkatkan hasil belajar peserta didik. Didapatkan hasil belajar peserta didik pada kelas eksperimen (menggunakan modul termokimia berbasis inkuiri terbimbing terintegrasi eksperimen) diperoleh rata-rata sebesar 84,48 dan kelas kontrol (menggunakan buku cetak karangan Unggul Sudarmo) diperoleh rata-rata sebesar 80,42. Hal ini membuktikan hasil belajar kelas eksperimen lebih tinggi dibandingkan kelas kontrol. 


\section{Referensi}

Alfirahmi, A. (2018). Pengembangan Modul Termokimia Berbasis Inkuiri Terbimbing Terintegrasi Eksperimen untuk Kelas XI SMA/MA. Menara Ilmu, 12(12).

Amri, Sofyan. 2013. Pengembangan dan Model Pembelajaran dalam Kurikulum 2013. Jakarta: Prestasi Pustaka

Andiasari, L. (2015). Penggunaan model inquiry dengan metode eksperimen dalam pembelajaran IPA di SMPN 10 Probolinggo. Jurnal Kebijakan dan Pengembangan Pendidikan, 3(1).

Andromeda, A., Bahrizal, B., \& Ardina, Z. (2016). Efektifitas Kegiatan Praktikum Terintegrasi dalam Pembelajaran pada Materi Kesetimbangan Kimia Kelas XI SMA/MA. EKSAKTA, 1, 45-51.

Astuti, S. P. (2015). Pengaruh kemampuan awal dan minat belajar terhadap prestasi belajar fisika. Formatif: Jurnal Ilmiah Pendidikan MIPA, 5(1).Departemen Pendidikan Nasional. 2008. Panduan Pengembangan Bahan Ajar. Jakarta: BSNP

Hanson, D. M. (2005). Designing process-oriented guided-inquiry activities. Faculty guidebook: A comprehensive tool for improving faculty performance, 305-308.

Irianto, Agus. 2015. Statistik : Konsep Dasar, Aplikasi, dan Pengembangannya. Jakarta: PT. Fajar Interpratama Mandiri

Maikristina, N., Dasna, I. W., \& Sulistina, O. (2013). Pengaruh penggunaan model pembelajaran inkuiri terbimbing terhadap hasil belajar dan keterampilan proses sains siswa kelas XI IPA SMAN 3 Malang pada materi hidrolisis garam. Jurnal Kimia FMIPA UNM, 1, 1-8.

Musfiqon \& Nurdyansyah. 2015. Pendekatan Pembelajaran Saintifik. Sidoarjo: Nizamia Learning Center Nasional, D. P. (2008). Panduan pengembangan bahan ajar. Jakarta: Depdiknas.

Novianty, I., Oktavia, S., \& Neena, Z. (2013). Efektivitas Penerapan Modul Materi Analisis Elektrokimia Berbasis Inkuiri Terbimbing Terhadap Hasil Belajar dan Persepsi Siswa Kelas XI Semester 1 Kompetensi Keahlian Kimia Analisis SMKN 7 Malang. Universitas Negeri Malang: jurnal-online. um. ac. id.

Roestiyah. 2008. Strategi Belajar Mengajar. Jakarta: PT. Rineka Cipta

Sevira, W. P. (2019, April). Effectiveness of chemical equilibrium module based guided inquiry integrated experiments on science process skills high school students. In Journal of Physics: Conference Series (Vol. 1185, No. 1, p. 012152). IOP Publishing.

Sugiyono. 2015. Metode Penelitian Kombinasi. Bandung: Alfabeta

Sugiyono. 2013. Metode Penelitian Manajemen. Bandung: Alfabeta

Susparini, N. T., Ashadi, A., \& Masykuri, M. (2016). Pengaruh Model Pembelajaran Inkuiri Terbimbing Dan Inkuiri Bebas Termodifikasi Pada Materi Termokimia Terhadap Keterampilan Berpikir Tingkat Tinggi Dan Hasil Belajar Siswa Kelas XI SMA Negeri 1 Sukoharjo Tahun Pelajaran 2015/2016. Jurnal Pendidikan Kimia, 5(2), 44-51.

Straumanis, A., \& Simons, E. A. (2010). Process Oriented Guided Inquiry Learning. 